\title{
大都市区农村土地非农化空间特征及机理 以广州市为例
}

\author{
刘 樱 ${ }^{1}$, 周春山 ${ }^{1 *}$, 黄婉玲 ${ }^{1}$, 朱倩琼 ${ }^{2}$ \\ (1. 中山大学地理科学与规划学院, 广州 510275; \\ 2. 北京大学深圳研究生院城市规划与设计学院, 广东 深圳 518055)
}

\begin{abstract}
摘 要: 随着国家对 “三农”问题的关注以及新型城镇化、城乡统筹、新农村建设等一系列重大战略决策的提出,农村 聚落的内容再次成为地理学的研究热点。大都市区作为快速城镇化和生产生活要素集聚的重点区域, 其农村聚落 的用地变化快速且复杂, 成为了农村聚落研究的重要内容。本文利用农村土地非农化指数, 将 2013 年广州市农村 聚落分为农耕型农村聚落、非农化起步型农村聚落、非农化发展型农村聚落、非农化主导型农村聚落、非农化型农 村聚落五种。结合 GIS 空间分析, 对广州市农村土地非农化空间结构进行了研究, 得出以下结论: (1)从市域角度, 农村聚落土地非农化总体呈现出围绕大都市内核随距离增加而衰减, 由外向内农村聚落土地非农化程度逐步升 高。(2)各区层面,农村土地非农化程度受副中心城镇化发展水平影响显著,近郊区域呈现面状圈层化分布,远郊 则表现出沿道路的线状分布特点。(3从局部尺度, 重大基础设施对周边农村聚落的土地非农化发展有较大拉动作 用, 导致高土地非农化农村聚落点状出现。随后采用多元线性回归、地理探测器等方法, 确定村内路网密度、与主 城距离、流动人口、村集体收人、村民人均收人为影响农村土地非农化水平的主要因素, 并在此基础上初步分析各 因子对大都市区农村聚落土地非农化的影响机制。本文对如何利用农村非农化进程促进城市发展、优化调控农村 土地利用和规划村庄发展提供一定的借鉴。
\end{abstract}

关 键 词:农村土地非农化; 空间特征;形成机理;农村聚落;大都市区;广州市

\section{1 引言}

改革开放以来计划经济向市场经济的转轨促 使传统农村聚落由自给自足的封闭系统向更为开 放的城乡关系转变, 土地、资本及劳动力等生产要 素的流动性增强, 推动农村聚落土地非农化快速发 展。这一进程正通过城镇用地扩张、产业结构演 变、人口流动、基础设施建设等方式推动农村地区 生产要素分化和重组, 深刻地改变了传统的农村用 地空间结构。在这一趋势下, 农村地区非农化发展 速度大幅增加, 而非农化的空间表现就是农村非农 用地的演变和发展。

全球金融危机后中国的城镇化正经历由生产
要素驱动向科技驱动、企业主导向以人为本、城乡 二元向城乡融合、高速增长向平稳增长转变的时 期, 个人、科技的驱动作用越发重要,这一特征在大 都市区表现更为明显,其农村聚落非农化也呈现新 的特征。对于外向型经济特征明显的广州市, 在城 镇化发展新特点影响下, 农村土地非农化的发展更 加复杂, 城乡融合趋势更明显, 研究其农村土地非 农化空间特征和机制能为城镇化的健康发展、城乡 土地集约利用和二元体制的优化改善及农村转型 发展等方面具有较强的理论和实践意义。

农村聚落的研究大致始于 19 世纪, 经历定性描 述和基础理论构建时期、理论发展与计量和模式化 研究时期、空间分析与人本主义研究时期的发展。

\section{收稿日期: 2017-08-28; 修订日期: 2018-01-12。}

基金项目:国家社会科学基金项目(17BRK010) [National Social Science Foundation of China, No.17BRK010]。 作者简介: 刘妲(1989-), 男, 河南南阳人, 博士研究生, 主要从事城市地理与农村地理的研究, E-mail: 392145348@qq.com。 通讯作者: 周春山(1964-), 男, 河南信阳人,博士, 教授, 主要从事城市内部空间结构、城市地理、城市与区域发展、规划等方面 的研究,E-mail: zhoucs@mail.sysu.edu.cn。 
研究内容从早期的农村聚落形成发展、空间形态、 布局与自然环境的相互关系(白吕纳, 1935; 林超, 1938; 金其铭, 1988; 许学强等, 1996)、农业区位论、 农村聚落空间演变(沃尔特-克里斯塔勒, 1933; 费 孝通, 1998)发展到农村区位条件、类型和职能划 分、城乡关系的相关研究(Pacione, 1984; 张小林, 1996)再发展到农村聚落的空间可视化分析模拟、 农村聚落转型发展 (Erickson et al, 2002; Antrop, 2004)、农村景观、生态环境和内部结构(乔家君等, 2006; 晨光等, 2015; 杨忍等, 2016)、农村规划(冯健 等, 2008)以及基于人本思想的人类决策对农村聚 落演变的影响、农村社区与农村社会问题的探讨 (Nelson, 2001; Brown, 2005; 刘彦随等, 2009)。

农村要素的非农化和城镇化是现代化的重要 标志,农村非农化的健康发展和新型城镇化进程相 一致。城乡二元结构导致的农村衰退、资源浪费等 矛盾日益突出, 城乡一体化和统筹城乡发展成为了 新型城镇化发展的新要求。在此要求下,农村要素 非农化逐渐展成为了学者们关注热点, 内容涉及农 村人口要素的非农化(谢长青等, 2008; 龙冬平等, 2014)、就业非农化(苑韶峰等, 2017)、产业非农化 (杨忍等, 2015)以及农村非农化与城镇化相互关系 的探讨(曹广忠等, 2016)。而农村土地要素作为空 间景观上最直接的体现,其非农化成为近几年的研 究重点, 目前学者们主要聚焦在农村土地非农化非 农化的制度、政策优化(孟宏斌, 2017)、农地保护(杨 志荣等, 2008) 以及农村土地非农化的空间演变及 影响因素(龙花楼, 2012; 李涛等, 2016)。

地理探测器是探测空间分异性, 揭示其背后驱 动因子的一种新的统计学方法(王劲峰等, 2017), 该 方法主要应用于医学(Wang et al, 2010)、自然科学 (Lou et al, 2016)、社会科学、城市化动力机制(刘彦 随等, 2012)、环境科学( Li et al, 2013)和农村问题等 方面,其中农村问题集中在农村贫困化(刘彦随等, 2017)、粮食问题(胡丹等, 2014)、聚落格局、空间分 布和农村用地格局(杨忍等, 2011; 杨忍等, 2013)。

农村土地非农化作为农村城镇化的空间体现， 关于其空间演变的驱动机制和影响因子分析成为 各学者关注的问题,成果不断涌现。大都市区作为 城镇化快速发展的区域,其都市内核对农村聚落的 非农化影响极为强烈,且不同区域之间也存在较大 的差异。目前关于特定都市区、农村土地非农化与 都市内核相互关系以及都市区内部不同区域差异 的研究相对较少。而广州市农村腹地广阔, 大都市
内核对农村土地非农化的影响深远。本文采用地理 探测器等方法分析了广州大都市区对农村腹地的辐 射影响关系及其农村聚落土地非农化的空间特征， 在城乡一体化的视角下构建了农村土地非农化的影 响机制,并着重分析了不同影响因子的空间差异,以 期丰富都市内核辐射下的农村聚落非农化发展研 究、非农化与城市经济发展的交互关系研究,并对农 村土地利用规划调控有一定的理论和实践意义。

\section{2 研究范围与研究方法}

\section{1 研究范围界定}

大都市区主要空间特点为: 具有一个城镇化水 平高度发展的核心区,并具有大面积的农村腹地区 域,非大都市区农村腹地往往偏小。2013 年广州市 域总面积为 $7434 \mathrm{~km}^{2}$, 其中农村总面积为 5650.73 $\mathrm{km}^{2}$, 占比 $76.01 \%$, 腹地面积广大, 且内核空间表征 突出,大都市特征显著。

本文选取番禺区、花都区、南沙区以及远郊的 增城市、从化市(广州市代管,2014年撤市设区)和白 云区、黄埔区、萝岗区(2014年与黄埔区合并)的行政 村用地构成广州市大都市区的农村腹地; 而海珠 区、天河区、越秀区和荔湾区等完全城镇化区域和 白云、黄埔、萝岗等近郊高度城镇化区域用地构成 大都市区的核心(图 1)。剔除无效数据后样本共包 含全市 1107 个行政村。

\section{2 研究数据来源}

本文利用广州市村域土地利用现状(2013 年)、 广州市村庄规划数据库(2013 年)和行政区划数据 (2013 年),运用 GIS 空间分析技术探讨农村用城镇 化程度的空间分布、分异特征,结合广州市村庄规 划现状调查数据(2013 年)和新农村规划以及各县区 地方志(2013 年)、广州市统计年鉴(2013 年)等文件 中涉及的社会经济数据, 采用定量和定性研究相结 合的方法,探讨广州大都市区农村土地非农化程度 发展影响因素及形成机制。

\section{3 研究方法}

本文主要采用的方法是 GIS 空间分析、线性回 归以及地理探测器的相关方法。

(1) 多元线性回归

多元线性回归是常用的解决地理问题的数学 分析方法之一,可探讨自变量与因变量统计学关 系, 从数量关系考虑各因素对农村土地非农化水平 的影响。该模型中各因素的显著性水平可作为其 


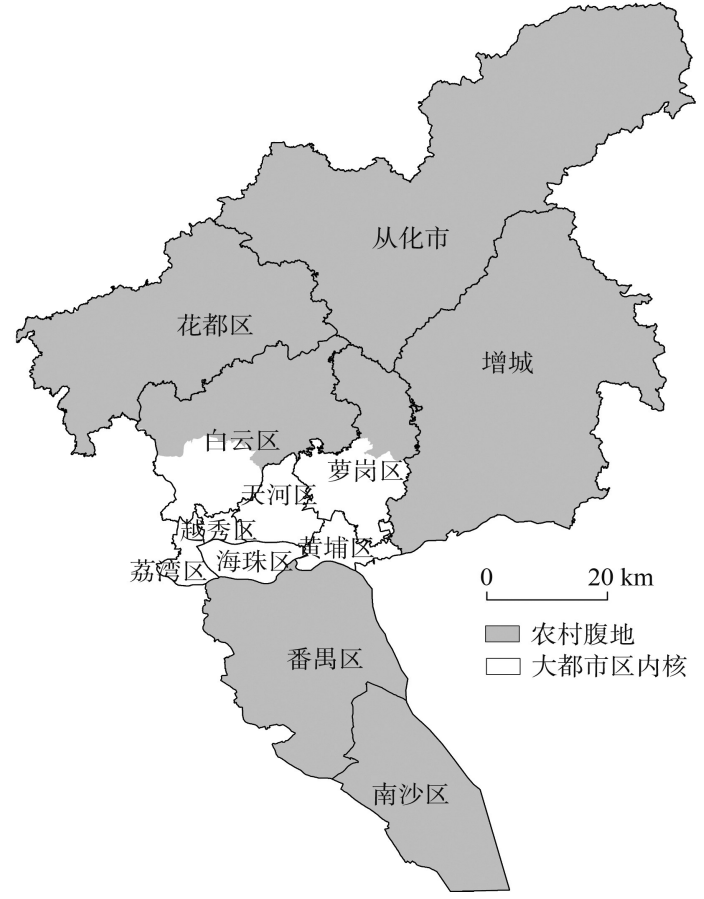

图 1 研究区范围界定图

Fig.1 The study area

是否是主要影响因素的判断标准。模型表达式为:

$$
Y=a_{0}+a_{1} F_{1}+a_{2} F_{2}+\cdots+a_{n} F_{n}
$$

式中: $Y$ 是农村土地非农化水平; $F_{1} 、 F_{2} 、 \cdots 、 F_{n}$ 为 影响农村土地非农化水平的因素; $a_{1} 、 a_{2} 、 \cdots 、 a_{n}$ 为 各农村土地非农化水平影响因素的回归系数; $a_{0}$ 为 截距(常数)。

(2) 地理探测器

相关研究表明,地理探测器方法在探索地理现 象空间分异十分有效, 因而选取地理探测器为研究 广州市农村土地非农化的空间分异及其形成机制 的方法。影响因素的地理探测力值 $q$ 的表达式为:

$$
q_{D, U}=1-\frac{1}{n \sigma_{U}^{2}} \sum_{i=1}^{m} n_{D, i} \sigma_{U_{D, i}}^{2}
$$

式中: $q_{D, U}$ 为农村土地非农化水平 $D$ 、影响因素 $U$ 的探测力值; $n$ 为全市行政村的个数; $m$ 为次级分区 行政村的个数(自然断点法获得); $n_{D, i}$ 为次级分区 内行政村的个数; $\sigma_{U}^{2}$ 为全市范围内农村土地非农 化水平的方差; $\sigma_{U_{D, i}}^{2}$ 为次级分区范围内农村土地非 农化水平的方差; $q_{D, U}$ 取值区间为 $[0,1], q_{D, U}$ 值越 大, $U$ 因素对农村土地非农化水平的影响程度越高。

\section{3 广州市农村土地非农化的空间特征}

土地非农化作为城镇化程度重要的衡量指标,
也是城镇化在现实中最直观的体现, 本文采用农村 土地非农化水平指数进行量度和分析。农村土地 非农化水平是指某一时间截面下,农村聚落中非农 建设用地占总用地的比例, 是农村土地非农化程度 的量度指标, 具体算法为:

农村土地非农化水平=农村非农建设用地/农 村土地总量(水域除外)

农村非农建设用地包括居民点建设用地、区域 交通设施用地、区域公用设施用地、工业、商业用 地、特殊用地、采矿用地等,此外总量还包括农业用 地、未利用地、绿地等用地类型。对广州市 1107 个 行政村进行测算,采用自然断点法,结合村庄相关社 会、自然数据并结合实地调研对其进行分类(表 1$)$; 通过 GIS 软件对不同类型的农村聚落进行空间分 析, 具体的空间布局如图 2。

\section{1 市域角度, 农村聚落土地非农化水平总体上从 大都市内核向外随距离增加而降低}

从整体上看, 广州市农村聚落的非农化水平随 其与大都市核心的距离增加而降低, 基本上遵循由 外向内呈现农耕型农村聚落一非农化起步型农村 聚落一非农化发展型农村聚落一非农化主导型农 村聚落一非农化型农村聚落的规律。一方面, 土地 非农化率较高的农村聚落(非农化主导型、非农化 型)主要集中在大都市内核的近郊区域,如番禺(外 来人口集聚地), 花都(工业副中心), 增城南部和西 部(靠近黄埔、萝岗旧工业区, 承接主城工业外扩的 区域)以及白云区北部(紧邻主城区域)的农村土地 非农化率也较高。这些区域作为传统的城市腹地, 区位、资源优势强促进区域农村聚落自发非农化的 快速发展; 另一方面, 广州市工业、企业、流动人口 等主要集中在城市近郊的天河、白云、黄埔、番禺等 近郊区域(周春山等,2004; 高军波等 2010), 大量生 产要素和流动人口向近郊集聚, 推动了一批以工 业、商业、房屋租赁业务为主产业的农村聚落涌现, 这些外部力量提升了农村土地非农化水平。

与之相对的,农村土地非农化程度低的区域主 要集中在远离大都市内核的增城东部和北部、从化 区域,地形、外来人口以及基础设施的先天不足导 致农村聚落自发土地非农化的发展受到限制, 工业 化、城镇化发展滞后, 区域仍以传统的农业为主要 支撑, 经济发展水平有限; 同时, 远离大都市内核的 区位劣势、行政区划和规划的限制，区域受到大都 市辐射有限, 外部动力满乏同时受到城市规划和定 位的限制，区域整体土地非农化发育水平不足。 
表 1 广州农村聚落类型示意表

Tab.1 Types of rural settlements in Guangzhou City, 2013

\begin{tabular}{|c|c|c|c|c|}
\hline 农村聚落名称 & 土地非农化指数 & 个数 & 分布 & 特点 \\
\hline 农耕型农村聚落 & $0 \% \sim 12.5 \%$ & 396 & $\begin{array}{l}\text { 集中分布在从化、增城、南沙等城市远郊区域 } \\
\text { 和部分例如白云山附近自然坡度较大的区域 }\end{array}$ & $\begin{array}{l}\text { 以传统农业为主导产业, , 域非农化程度极 } \\
\text { 低,非农用地主要以农村居住用地为主 }\end{array}$ \\
\hline $\begin{array}{l}\text { 非农化起步型农 } \\
\text { 村聚落 }\end{array}$ & $12.5 \% \sim 25 \%$ & 273 & $\begin{array}{l}\text { 多聚集在增城、从化和南沙的大部分区域以及 } \\
\text { 花都、番禺区的外围地区 }\end{array}$ & $\begin{array}{l}\text { 以一产为主导产业, 工业化有了初步发展, } \\
\text { 非农用地主要由少量工业及居住用地构成 }\end{array}$ \\
\hline $\begin{array}{l}\text { 非农化发展型农 } \\
\text { 村聚落 }\end{array}$ & $25 \% \sim 50 \%$ & 254 & $\begin{array}{l}\text { 主要分布在广州中郊、近郊的番禺、花都和白 } \\
\text { 云区域,对行政区内部而言,多集中在副中心 } \\
\text { 的中郊区域 }\end{array}$ & $\begin{array}{l}\text { 一般以第二产业为主,工业化得到了较好的 } \\
\text { 发展,基础设施得到了一定发展, 大量工业 } \\
\text { 用地是非农用地的主要成分 }\end{array}$ \\
\hline $\begin{array}{l}\text { 非农化主导型农 } \\
\text { 村聚落 }\end{array}$ & $50 \% \sim 75 \%$ & 106 & $\begin{array}{l}\text { 集中分布在靠近主城内核的番禺、增城、白云 } \\
\text { 区以及靠近花都副中心的部分区域,从化和增 } \\
\text { 城也有少量分布 }\end{array}$ & $\begin{array}{l}\text { 以第二产业或第三产业为主, 工业高度发展 } \\
\text { 并拉动了第三产业的形成发展,非农用地主 } \\
\text { 要以二三产用地和设施用地为主 }\end{array}$ \\
\hline $\begin{array}{l}\text { 非农化型农村 } \\
\text { 聚落 }\end{array}$ & $75 \%$ 以上 & 78 & $\begin{array}{l}\text { 多分布于大都市内核附近和城市副中心附近, } \\
\text { 在一些重大基础设施(空港、海港、大学城、地铁 } \\
\text { 站)也有点状分布 }\end{array}$ & $\begin{array}{l}\text { 以二产或三产为主要业态, 城镇化、非农化 } \\
\text { 高度发达,村庄非农用地多元化,包含产业 } \\
\text { 用地、基础设施、城镇建设用地等 }\end{array}$ \\
\hline
\end{tabular}

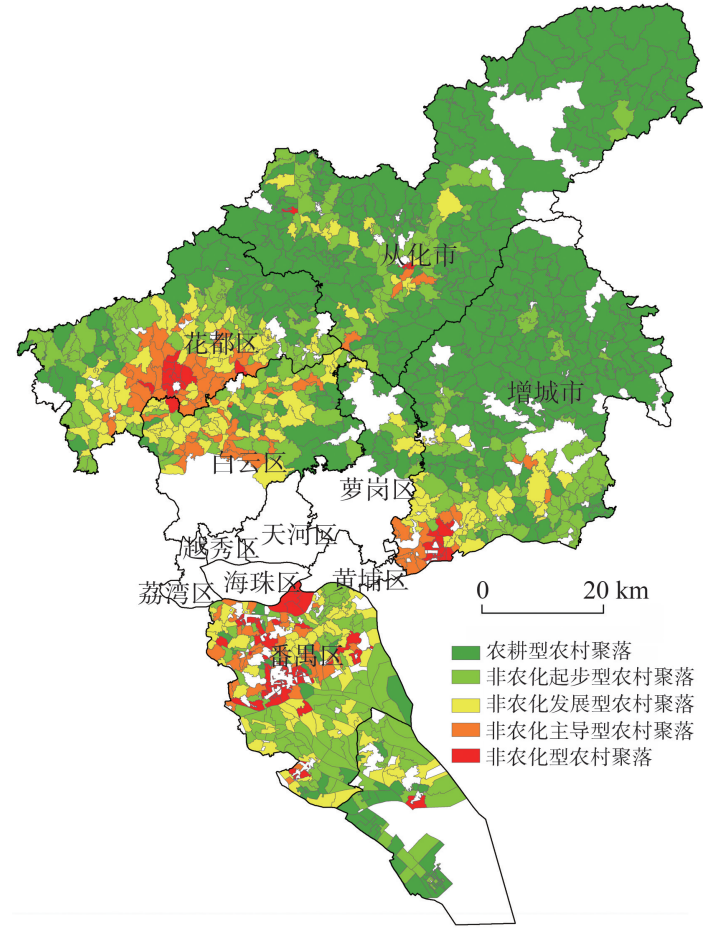

图 2 广州市农村土地非农化空间特征示意图

Fig.2 The spatial features of non-agricultural degree of rural settlements

\section{2 各区角度, 受副中心影响, 近郊农村土地非农化 呈现圈层化特征, 远郊则呈现线状特征}

大都市内核扩张产生了诸多问题促使广州市 采取多中心的发展思路,城市副中心实力得到了提 升,带动周边农村聚落的发展。发展较早且城镇化 程度较高的花都、番禺副中心在工业和外来人口的 集聚效应下,农村聚落土地非农化水平较高, 但由 于区域自身禀赋和副中心辐射能力有限, 整体上以 行政中心为核心向外土地非农化水平呈现衰减的 面状圈层化分布(图 3a)。而增城、从化和南沙等副
中心, 发展时间较短,辐射拉动作用较弱, 区域内农 村土地非农化的外部拉力来源仍是主城内核, 以区 域发展初期的道路经济为主,土地非农化较高的农 村聚落呈现沿主干道分布的现状特征(图 3b)。

各个行政区受区位、行政区划、资源禀赋、基础 设施、自然条件等因素差异的影响,农村土地非农 化的发展程度相差较大,发育程度较高的主要是番 禺区 $(50.03 \%)$ 、花都区 $(34.01 \%)$ 以及白云区 $(32.57 \%)$ 等近郊区,一方面由于自身区位优势和主城基础设 施的不断覆盖, 形成了一批以二产、三产为主导产 业的非农化主导型农村聚落和非农化型农村聚落; 另一方面,作为较早纳人市辖区的几个区域,其承 担了主城区产业的外迁和流动人口的迁移,而生产 要素的外迁再一次推动了区域工业化、土地非农化 的发展。由于产业集聚和人口集聚效应, 较高土地 非农化率的农村聚落分布呈面状组团分布特征。

农村土地非农化率较低的区域主要为从化市 (13.56\%)、增城市 $(17.55 \%)$, 其区位先天劣势较大, 加之地形等因素的限制, 生产要素难以聚集, 自发 工业化发展受限。此外,受行政区划的影响,其接 受大都市内核的辐射作用较弱。随着两区“撤市设 区”的完成,该区域也承担了主城区工业的外扩和 人口的外迁,但目前尚处于工业化和土地非农化的 初期,高土地非农化水平的农村聚落具有沿主要道 路分布的特点。从化较高土地非农化水平的行政 村多集中在 G45 国道和 S335 省道两侧,增城则集中 在广园快速路和广惠高速两侧。

\section{3 局部尺度, 重大基础设施往往引发周边农村聚} 落土地非农化程度快速提高

重大基础设施的建设往往能够带来大量的资 


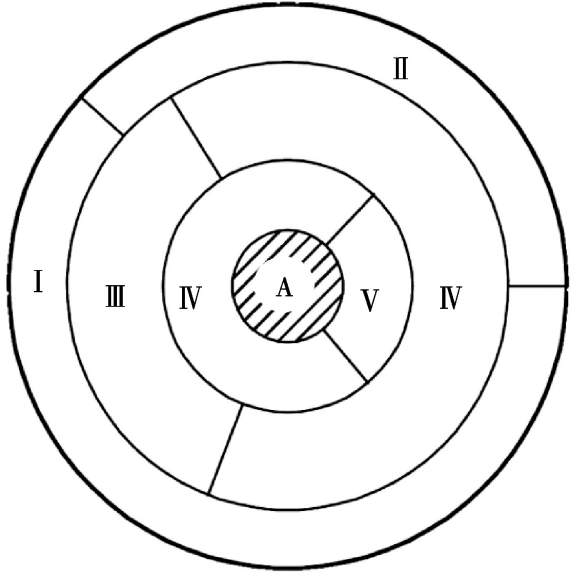

a. 近郊高发育程度副中心周边农村聚落 土地非农化空间结构

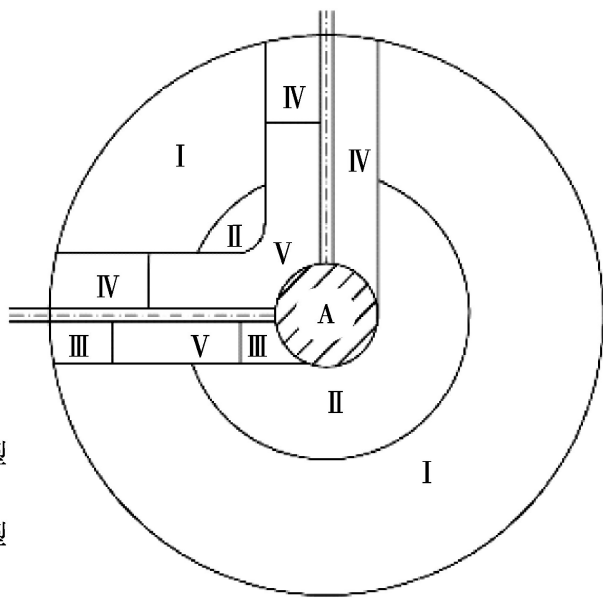

b. 远郊低发育程度副中心周边农村聚落 土地非农化空间结构

图 3 不同发育程度副中心周边农村聚落土地非农化空间结构示意图

Fig.3 Models of spatial distribution of rural land non-agricultural degree around sub-centers

金、企业以及外来人口,造成区域内生产要素的快 速集聚,对于珠三角这一典型的工业驱动城镇化发 展的区域而言, 生产要素的发展往往推动农村土地 的非农化进程。因此点状基础设施建设引起部分 农村土地非农化远水平高于周边。例如南沙港附 近的行政村,多为土地非农化水平在 $50 \%$ 以上的农 村聚落。且拥有南沙港的南沙区, 与同处于中远郊 的从化和增城相比, 其农村聚落土地非农化水平高 出将近 10 个百分点。

番禺、花都等区的部分农村聚落, 受白云机场、 火车南站和包含大量文教类基础设施的大学城建 设的影响, 其产业业态由农业发展为商贸服务业, 大量农村土地转为非农用地, 拉动了农村土地非农 化的发展。此外,地铁这一基础设施的建设降低了 出行时间和出行成本, 促进了近郊区域职住分离现 象的产生和发展, 人口逐渐向近郊区域集聚,其产 生的居住、消费等需求促使大量高土地非农化农村 聚落的出现。

\section{4 广州市农村土地非农化的影响因素}

本文参考相关成果 (万晔等, 2002; 姚龙等, 2015)并结合广州市农村聚落的实际情况, 选取最 能影响农村土地非农化水平特征的 4 个大类的影响 因子: 区位可达性因子(村内路网密度、与主城区距 离)、人口因子(户籍人口数量、外来人口数量、机械 增长率)、经济指标(村集体总收人、村民人均收人)、 土地利用类型因子(工业用地、商业服务业用地、村
庄建设用地、耕地、园地、林地、其他农用地)共 14 个 影响因子(表2):

利用多元线性回归模型对选取因子进行相关 性和多重共线性检验,选取最佳的影响因子组合。 回归分析发现, 村内路网密度 $\left(X_{1}\right)$,与主城区距离 $\left(X_{2}\right)$, 流动人口 $2012\left(X_{3}\right)$, 村集体收人 $\left(X_{4}\right)$, 村民人均 收人 $\left(X_{5}\right)$ 与农村土地非农化水平显著性较高, 为显 著因子组合, 相关系数 $R$ 分别为 $0.064 、 0.319 、 0.127$ 、 $0.169 、 0.221$; 而户籍人口数量、人口机械增长率、工 业用地、商业服务业用地、居住用地、耕地、园地、林 地、其他农用地 9 个因子显著性较低。分析得出如 下最优模型：

$$
\begin{aligned}
Y= & 26.442+0.064 X_{1}-0.319 X_{2}+0.127 X_{3}+ \\
& 0.169 X_{4}+0.221 X_{5}
\end{aligned}
$$

拟合优度 $R$ 为 0.90 , 调整后 $R^{2}$ 为 $0.95, d f$ 值为 10 , 模型的总体拟合较好, 5 个因素能在较大程度上 对农村土地非农化水平进行解释, 同时也表明农村 土地非农化是由多因素共同作用的结果。回归标 准系数表明,上述 5 个因素显著性水平指数均小于 0.05 , 表明这些因素对广州农村土地非农化水平差 异的影响较为显著,并且当 5 个因素共同作用时,农 村土地非农化 $(Y)$ 与村内路网密度 $\left(X_{1}\right)$ 、流动人口 $\left(X_{3}\right)$ 、村集体收人 $\left(X_{4}\right)$ 、村民人均收人 $\left(X_{5}\right)$ 呈显著正相 关,而与主城区距离 $\left(X_{2}\right)$ 呈显著负相关。

基于地理探测器, 利用农村土地非农化分级与 各因素的自然断点法分类进行空间耦合匹配分析 (图 4)。进一步根据地理探测器模型, 将村内路网密 度 $\left(X_{1}\right)$ 、与主城区距离 $\left(X_{2}\right)$ 、流动人口 $\left(X_{3}\right)$ 、村集体收 
表 2 广州市农村土地非农化影响因子

Tab.2 Influencing factors of rural land non-agricultural degree in Guangzhou City

\begin{tabular}{cl}
\hline 因子类型 & \multicolumn{1}{c}{ 因子名称 } \\
\hline 区位可达性 & 村内道路密度 \\
与口因子 & 与主城区距离 \\
& 户籍人口数量 \\
& 外来人口数量 \\
& 机械增长率 \\
经济指标 & 村集体收人 \\
& 村民人均收人 \\
土地利用类型因子 & 工业用地 \\
& 商业服务业用地 \\
& 村庄建设用地 \\
& 耕地 \\
& 园地 \\
& 林地 \\
& 其他农用地 \\
\hline
\end{tabular}

人 $\left(X_{4}\right)$ 、村民人均收人 $\left(X_{5}\right) 5$ 项指标分别与农村土地 非农化水平进行空间探测分析。对因变量农村土 地非农化水平 $(Y)$ 和 5 个主要因子进行分析,计算得 到各因子对农村土地非农化水平的决定力依次为 $0.11 、 0.28 、 0.38 、 0.22 、 0.24$ 。 5 个因子对农村土地非 农化的影响均较为显著。

综合多元线性回归和地理探测器的相关分析 结果, 最终确定村内路网密度 $\left(X_{1}\right)$ 、与主城距离 $\left(X_{2}\right)$ 、 流动人口 $\left(X_{3}\right)$ 、村集体收人 $\left(X_{4}\right)$ 、村民人均收人 $\left(X_{5}\right)$ 作 为影响广州市农村土地非农化水平的主导因子。

\section{5 广州市农村土地非农化空间特征形 成机理}

广州市农村土地非农化空间特征的形成是一 个复杂的过程,其中主导因子村内路网密度 $\left(X_{1}\right)$ 、与 主城距离 $\left(X_{2}\right)$ 作为交通通达性和联系紧密度重要的 因子,造成了农村聚落区位和基础设施的差异。流

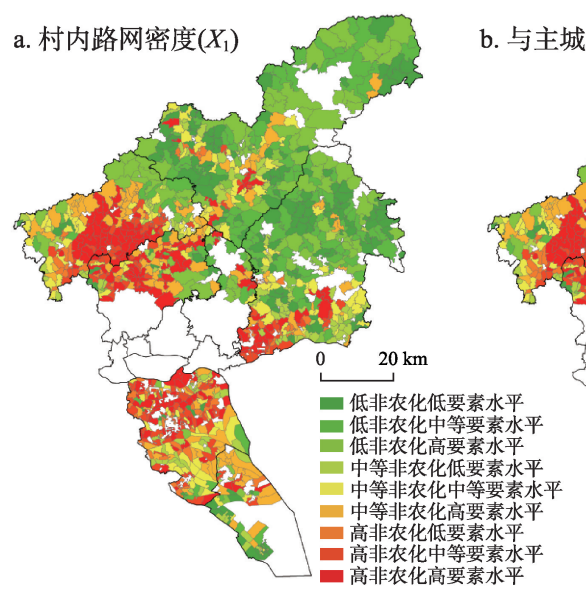

b. 与主城区距离 $\left(X_{2}\right)$

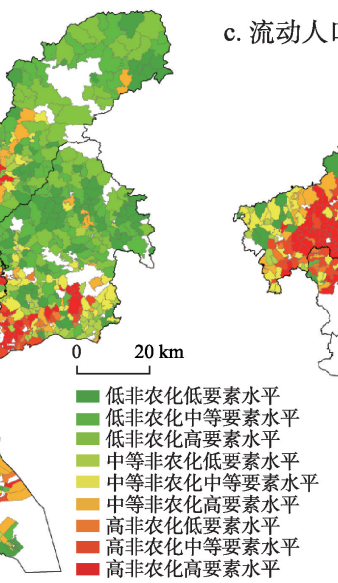

c. 流动人口 $\left(X_{3}\right)$

d. 村集体收人 $\left(X_{4}\right)$

e. 村民人均收人 $\left(X_{5}\right)$
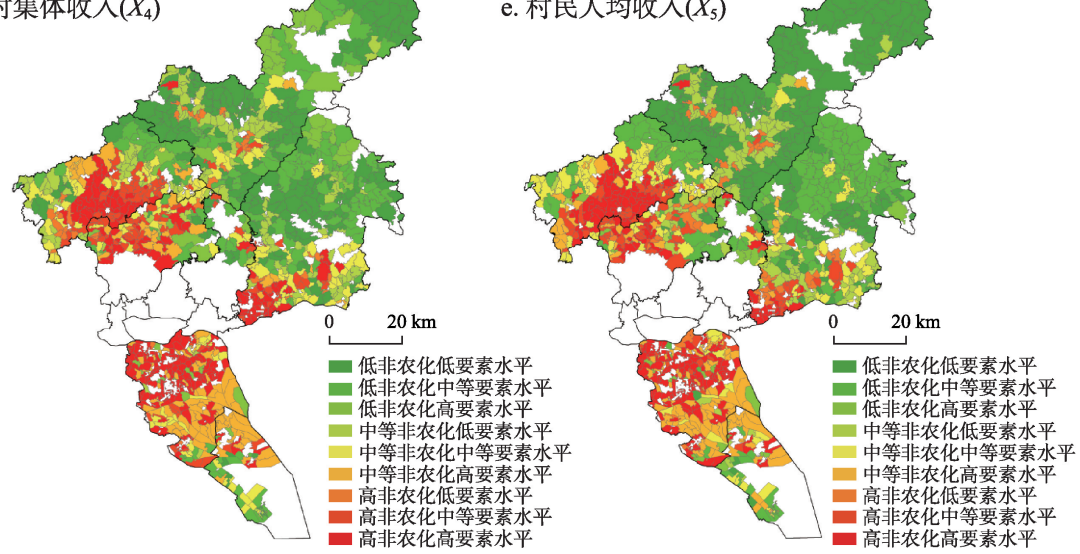

图 4 广州农村土地非农化水平与要素匹配空间分布

Fig.4 Spatial distribution of rural land non-agricultural degree influencing factors in Guangzhou City 
动人口 $\left(X_{3}\right)$ 因子作为生产生活的主体, 其劳动力的 经济属性和自身的生活属性主导了农村土地非农 化空间特征的形成。而作为农村聚落经济发展水 平和个人经济发展程度指标的村集体收人 $\left(X_{4}\right)$ 、村 民人均收人 $\left(X_{5}\right)$ 直接驱动了村庄第二产业和商贸服 务业的发展, 其他诸如城市规划、基础设施、管理水 平和重大节事则一定程度上对这一空间特征起到 了调节作用,具体的形成机理如图 5。

(1) 村内路网密度。作为农村聚落可达性和对 内对外交通连接性的主要指标, 是影响农村产业形 成和发展的重要因素。通常情况下, 交通便利、可 达性好的区域, 因为物流、人流以及信息流较快, 有 利于生产要素的集聚。对于珠三角而言, 工业化与 非农化表现出高度的相关性, 企业成为过去 20 年驱 动珠三角城镇化、非农化的主体, 路网密度高的农 村聚落, 因自身工业化的发展和外来企业的进驻, 土地非农化水平较高。

广州市路网密度较大的区域主要集中在白云、 花都和番禺部分工业集中区域和城市近郊区域, 其 农村土地非农化较其他区域高。而增城、从化的路 网密度较低, 以与主城区的主干道交通为主, 因此 构成了高非农化农村聚落的线状分布特点, 2 个区 域外围和花都北侧的部分农村聚落, 受地形等多方
面因素制约,路网密度极低,形成了农村聚落土地 非农化最低的洼地。从行政区来看, 路网密度随中 心向外衰减,故形成农村土地非农化水平也围绕行 政中心向外呈衰减的状况。由于城市轨道交通的 发展以及区域功能定位的转变, 一些农村土地非农 化推动力逐步由工业向服务业过渡, 路网密度的影 响减弱, 表现最明显的即为番禺区, 受功能定位、综 合交通的完善以及区域产业升级更新的影响, 路网 密度的影响力较低(图 6a)。

(2) 与主城区距离。是农村聚落区位优劣势的 重要指示因素, 也是农村聚落受主城核心经济与公 共服务辐射强弱的重要影响因素。相关研究表明, 广州的城镇化仍然是近郊城镇化为主(周春山等, 2015),外来人口、企业以及基础设施的分布多集中 在近郊区域,近郊农村聚落更容易得到产业发展的 机会。此外,随着主城产业外迁,近郊生产要素集 中区域往往成为外迁的首选, 促进工业化和农村土 地非农化进程的加快。中远郊区域由于距离原因, 生产要素、基础设施不够完备, 难以吸引外迁企业, 导致农村土地非农化进程发展缓慢。

由于大都市区农村腹地辽阔, 远郊农村聚落容 易受到其他辐射中心的影响。一方面,多中心的发 展战略促进副中心的形成与发展, 部分村庄的辐射

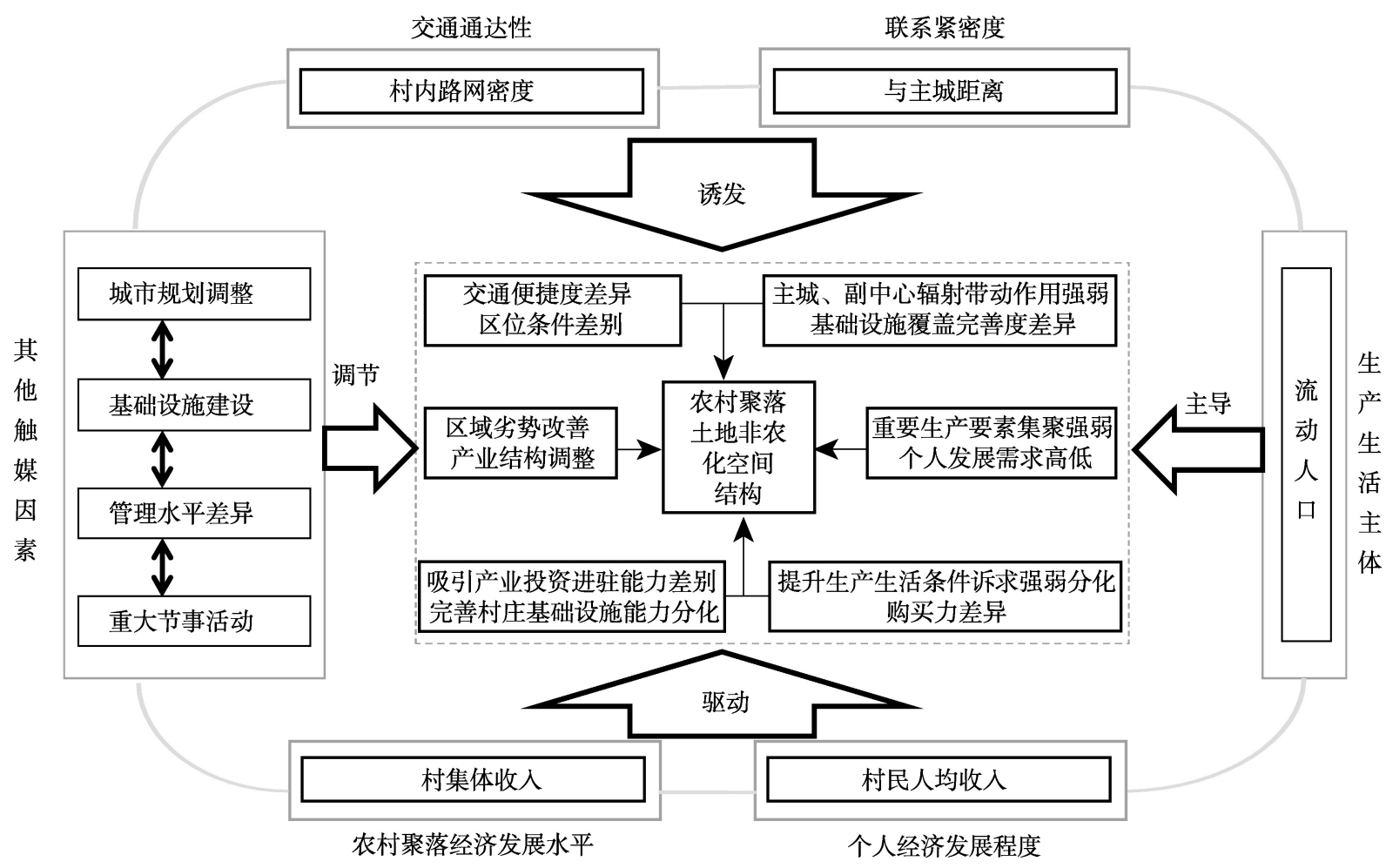

图 5 大都市区农村聚落土地非农化影响机理示意图

Fig.5 Mechanism of the spatial distribution of rural land non-agricultural degree in metropolitan areas 
中心由主城内核逐步转向为副中心内核, 副中心周 边的区域,农村土地非农化水平得到了一定提高, 其提高程度和副中心的发育程度呈正比。另一方 面, 受区域一体化和产业集群化发展的影响, 部分 远郊农村聚落受到临近城市内核的辐射和影响, 工 业化得到了一定的发展, 土地非农化水平得到了提 升。例如花都与佛山相邻以及增城与东莞相邻的 农村聚落, 土地非农化程度明显较高(图 6b)。

(3) 流动人口。该因素作为农村聚落重要的资 源要素和生产指标, 对广州农村土地非农化水平的 决定力最强。从人的经济属性角度看, 对于以劳动 密集型企业为主的珠三角地区来说流动人口作为 重要的生产要素, 能极大地推动产业的形成和发 展, 从而影响土地非农化水平。从人的社会生活属 性来看, 外来人口集聚能产生大量的居住、饮食、购 物和休闲需求, 可促生区域商业、房屋租赁等相关 服务业的发展, 拉动农村土地非农化的发展。

广州的外来人口主要集中在番禺、花都和增城 近郊区, 这些区域原有的乡镇工业较多, 大量就业机 会促进外来人口进人, 而围绕着工业村庄, 形成大量 的服务型村庄, 促进了高土地非农化农村聚落面状 布局的特点。而从化、增城的外来人口相对较少, 除 行政中心周边有少量的外来人口集聚形成的高土地 非农化水平农村聚落外, 整体农村土地非农化水平 较低。另外, 重大基础设施往往能促进外来人口的 集聚, 从而拉动农村土地非农化水平的提升, 例如南 沙港附近、包含大量文教基础设施的大学城周边等 区域, 高土地非农化农村聚落呈点状分布(图 6c)。

(4) 村集体收人。该因素作为农村聚落经济水 平重要的指标, 是村庄发展程度和村政府服务能力 的体现。一般状况下, 村集体的收人与村政府服务 能力和村庄建设能力成正比, 收人越高, 基础设施 的完善、建设力度越高。高集体收人的行政村的主 导业态多以工业和服务业为主, 多数拥有自己的村 办企业,其非农化水平也较高。而村集体的财政收 人越低, 则意味着村政府相应的建设能力和服务能 力受资金制约较大, 多以传统的农耕产业为主, 产 业难以带动土地非农化的发展。

广州市村集体收人较高的行政村多集中在番 禺区、白云区,低水平的多集中在花都、南沙的农村 聚落。指标较高的行政村多分布在地铁出口附近, 主要产业除工业之外, 服务业和例如动漫在内的新 兴产业也逐步发展。而增城和从化的大部分村庄, 由于先天农村工业化发展不足, 加之承接主城产业
外迁尚处于初级阶段, 工业化水平不高, 非农化程 度也相应较低(图 6d)。

(5) 村民人均收人。村民收人也是农村聚落经 济水平一个典型指标, 对应着村庄居民的购买力、 生活需求和村庄经济的发展状况。村民人均收人 较高的农村聚落, 居民主要从事的行业以第二第三 产业为主, 若本村有相应产业, 则对应村集体收人 较高的状况; 另一种情况则是周边城镇或农村有较 好的就业机会, 村民外出打工提升自身的收人水 平, 促进村民对居住条件、生活条件、通勤条件改善 的愿望, 间接推动了村庄基础设施、居住用地的建 设和增加, 从而引发土地非农化水平的提高。

广州市村民人均收人较高的农村聚落集中分布 在番禺、南沙和花都地区, 且南部各区高于北部。这 些区域都有二、三产支撑, 大部分村民从事行业也以 二、三产为主,整体城镇化水平较高。而从化和增城 等远郊区域就业机会较少, 虽有一定量的农村居民 外出从事二、三产业工作, 但大部分地区仍以第一产 业为主,农村土地非农化水平有限(图6e)。

从上述各个区域对比来看,农村聚落土地非农 化发展初期, 区位因素(与主城距离)和交通要素(路 网密度)作为主要因素, 对农村土地非农化起到支 配作用,道路经济成为土地非农化的催化剂; 而后 随着经济和技术的发展以及城市结构的转变, 区位 和交通要素重要性下降,作为生产要素的外来人口 等生产要素成为农村土地非农化的重要推手, 促进 农村聚落经济水平和土地非农化水平提升。而为 了推动产业和经济发展,部分行政村利用集体收人 完善基础设施、办公设施等, 土地非农化水平再次 升高。而随着村民收人的增加和外来人口的集聚, 生活需求逐步取代生产需求, 商业、房屋租赁等服 务业推动村庄业态升级和土地非农化程度的提高。

农村土地非农化水平的空间格局是一个复杂过 程产生的结果, 其受多种要素共同作用产生(表 3)。 除了可以定量的因素之外,一些其他要素也对其有 较大影响。(1)城市规划对于区域功能的定位容易 引发企业和流动人口等的流动, 从而影响土地非农 化水平。如从化被划定为水源保护区和生态功能 保护区之后, 原有的石粉、采矿行业迁出,农村土地 非农化发展更加缓慢; (2)行政区划的调整导致先划 人的番禺、花都副中心的发展程度远高于从化、增 城区域, 土地非农化水平差异明显; (3)重大节事活 动例如亚运会等, 大量场馆、分会场建设的用地需 求极大地推动了副中心和周边农村聚落的土地非 

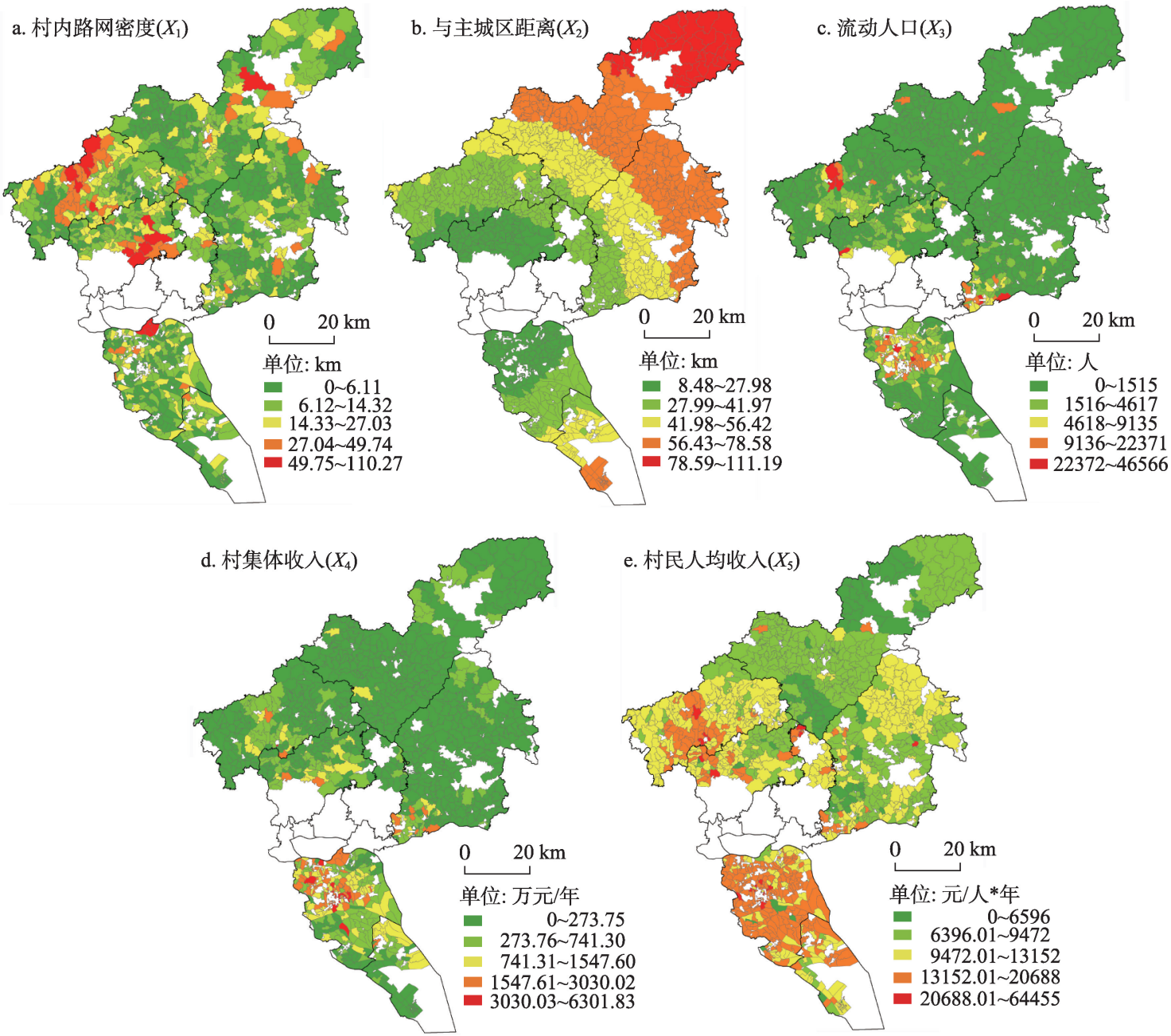

图 6 广州市农村土地非农化主导因素分级示意图

Fig.6 Key factors affecting rural land non-agricultural degree in Guangzhou

表 3 不同行政区各因素影响强弱分析表

Tab.3 Influences of the factors affecting rural land non-agricultural degree in different districts of Guangzhou City

\begin{tabular}{|c|c|c|c|c|c|c|c|c|c|c|c|c|c|c|c|}
\hline & \multicolumn{3}{|c|}{$X_{1}$ 村内路网密度 } & \multicolumn{3}{|c|}{$X_{2}$ 主城距离 } & \multicolumn{3}{|c|}{$X_{3}$ 流动人口 } & \multicolumn{3}{|c|}{$X_{4}$ 村集体收人 } & \multicolumn{3}{|c|}{$X_{5}$ 村民人均收人 } \\
\hline & 高 & 中 & 低 & 高 & 中 & 低 & 高 & 中 & 低 & 高 & 中 & 低 & 高 & 中 & 低 \\
\hline 番禺区 & & & V & $V$ & & & $V$ & & & V & & & V & & \\
\hline 花都区 & V & & & & & V & V & & & V & & & & V & \\
\hline 白云区 & & V & & $V$ & & & $V$ & & & & V & & & V & \\
\hline 萝岗区(现黄埔区) & V & & & & $\checkmark$ & & V & & & V & & & & V & \\
\hline 增城市 & V & & & & & V & V & & & & V & & & V & \\
\hline 从化市 & V & & & & & $V$ & V & & & & & V & V & & \\
\hline 南沙区 & & V & & & V & & V & & & V & & & & V & \\
\hline
\end{tabular}

农化进程; (4)城乡管理以及企业管理对于产业、人 口的布局发展均有一定影响, 对农村地区的土地非 农化也会产生一定的作用。

\section{6 结论与讨论}

大都市区作为城市发展的高级阶段,集聚了大
量的人口、企业和资金等要素,城镇化过程强劲,用 地需求旺盛。中心城区强大的经济辐射和土地需 求促使周边农村聚落产业提升及用地性质发生变 化,从而带动周边农村聚落土地非农化的发展。

(1) 整体上,广州市农村土地非农化水平及农 村聚落随着与大都市内核的距离增加而逐步衰减, 
而各副中心随发展程度不同,农村非农化空间分布 由线状向面状过渡。广州市城镇化目前主要还是 以近郊城镇化为主, 远郊区域的工业化、城镇化进 程受限。从各区来看, 大体上农村土地非农化水平 基本围绕各区副中心内核向外随距离衰减,但显著 性与副中心的发育程度呈正相关。番禺、花都副中 心发育程度较高, 农村土地非农化水平围绕副中心 呈面状圈层化分布; 而从化、增城则由于发育时间 较短, 副中心辐射能力较弱, 土地非农化程度较高 的农村聚落集聚在主干道两侧, 呈线状集中分布。 随着副中心的继续发展和基础设施、公共服务的逐 步覆盖，区域间差异将为逐步缩小，线状分布的空 间特点将逐步演化为面状圈层化分布。

(2) 大都市区农村土地非农化的影响机制复杂 和多元化, 影响要素随着非农化发展程度呈现由自 然要素向生产要素进而向生活要素转变的趋势。 除交通、经济、人口等方面可以量化的指标外,城市 发展思路、城市规划管理、跨城市之间的区域合作 和分工, 以及对环境、社会平等、生活质量等方面的 多元关注都对农村土地非农化产生不同的影响。 随着农村聚落非农化的发展, 主导因素则呈现由自 然、区位因素向生产、产业要素过渡,最终向生活、 个人要素发展的状况。

(3) 在大都市区快速城镇化和工业化的影响 下,农村土地非农化发展是必然的趋势。如何充分 利用非农化的过程促进城市经济的发展成为重点 考虑的问题之一。科学、合理的新农村规划显得十 分必要。在高速发展的农村城镇化背景下,如何构 建一个真正留得住文化, 而又兼顾农村居民发展诉 求的新农村系统也是十分重要的研究课题。

\section{参考文献(References)}

白吕纳. 1935. 人地学原理 [M]. 任美愕, 李旭旦, 译. 南京: 钟 山书局. [Brunhes J. 1935. La geographie humaine[M]. Ren M E, Li X D, Trans. Nanjing, China: Zhongshan Press.]

曹广忠, 马嘉文. 2016. 中国城镇化与非农化的空间分异、相 互关系和形成机制 [J]. 地理研究, 35(12): 2249-2260. [Cao G Z, Ma J W. 2016. Spatial pattern, mutual relationship and driving forces of China's urbanization and non-agriculturalization[J]. Geographical Research, 35(12): 22492260.]

晨光, 张凤荣, 张佰林. 2015. 农牧交错区农村居民点土地利 用形态演变: 以内蒙古自治区阿鲁科尔沁旗为例 [J]. 地 理科学进展, 34(10): 1316-1323. [Chen G, Zhang F R, Zhang B L. 2015. Change in land use form of rural settle- ments in the farming-pastoral transitional zone: A case study in Aluke'rqin Banner, Inner Mongolia[J]. Progress in Geography, 34(10): 1316-1323.]

费孝通. 1998. 乡土中国[M]. 北京: 北京大学出版社. [Fei X

T. 1998. Earthbound China[M]. Beijing, China: Peking University Press.]

冯健, 刘玉. 2008. 江苏中小型集镇空间规划与乡村景观重 构 [J]. 资源科学, 30(5): 737-743. [Feng J, Liu Y. 2008. Restructuring the rural landscape and spatial planning of towns in Jiangsu Province[J]. Resources Science, 30(5): 737-743.]

高军波, 周春山, 江海燕, 等. 2010. 广州城市公共服务设施 供给空间分异研究 [J]. 人文地理, 25(3): 78-83. [Gao J B, Zhou C S, Jiang H Y. 2010. The research on the spatial differentiation of the urban public service facilities distribution in Guangzhou[J]. Human Geography, 25(3): 78-83.]

胡丹, 舒晓波, 尧波, 等. 2014. 江西省县域人均粮食占有量 的时空格局演变 [J]. 地域研究与开发, 33(4): 157-162. [Hu D, Shu X B, Yao B, et al. 2014. The evolvement of spatio- temporal pattern of per capita grain possession in counties of Jiangxi Province[J]. Areal Research and Development, 33(4): 157-162.]

金其铭. 1988 农村聚落地理 [M]. 北京: 科学出版社.[Jin Q M. 1988. The Geography of Rural Settlements [M]. Beijing, China: Science Press.]

李涛, 廖和平, 褚远恒, 等. 2016. 重庆市农地非农化空间非 均衡及形成机理 [J]. 自然资源学报, 31(11): 1844-1857.

[Li T, Liao H P, Chu Y H, et al. 2016. Spatial disequilibrium and its formation mechanism of farmland conversion in Chongqing[J]. Journal of Natural Resources, 31(11): 1844-1857.]

林超. 1938. 聚落分类之讨论 [J]. 地理, 6(1): 17-18. [Lin C. 1938. The disscussion of the type of the rural settlements [J]. Geography, 6(1): 17-18.]

刘彦随, 李进涛. 2017. 中国县域农村贫困化分异机制的地 理探测与优化决策 [J]. 地理学报, 72(1): 161-173. [Liu Y S, Li J T. 2017. Geographic detection and optimizing decision of the differentiation mechanism of rural poverty in China[J]. Acta Geographica Sinica, 72(1): 161-173.]

刘彦随, 刘玉, 翟荣新. 2009. 中国农村空心化的地理学研究 与整治实践 [J]. 地理学报, 64(10): 1193-1202. [Liu Y S, Liu Y, Zhai R X. 2009. Geographical research and optimizing practice of rural hollowing in China[J]. Acta Geographica Sinica, 64(10): 1193-1202.]

刘彦随, 杨忍. 2012. 中国县域城镇化的空间特征与形成机 理 [J]. 地理学报, 67(8): 1011-1020. [Liu Y S, Yang R. 2012. The spatial characteristics and formation mechanism of the county urbanization in China[J]. Acta Geographica Sinica, 67(8): 1011-1020.]

龙冬平, 李同昇, 苗园园, 等. 2014. 中国农村人口非农化时 
空演变特征及影响因素 [J]. 地理科学进展, 33(4): 517530. [Long D P, Li T S, Miao Y Y, et al. 2014. Spatio-temporal characteristics and impacting factors of non-agriculturalization of China's rural population[J], Progress in Geography, 33(4): 517-530.]

龙花楼, 邹健, 李婷婷, 等. 2012. 乡村转型发展特征评价及 地域类型划分: 以“苏南-陕北”样带为例 [J]. 地理研究. 31 (3): 495-506. [Long H L, Zou J, Li T T, et al..2012. Study on the characteristics and territorial types of rural transformation development: The case of "Southern Jiangsu-Northern Shaanxi" transect[J]. Geographical Research, 31(3): 495-506.]

孟宏斌. 2017. 农地非农化征用中的农民土地增值收益权保 护 [J]. 改革与战略, 33(1): 90-94. [Meng H B. 2017. On the protection of farmers' interest in rural land value-add rights in the processes of rural land acquisition[J]. Rerormation and Strategy, 33(1): 90-94.]

乔家君, 李小建. 2006. 村域人地系统状态及其变化的定量 研究: 以河南省三个不同类型村为例 [J]. 经济地理, 26 (2): 192-197. [Qiao J J, Li X J. 2006. A quantitative study on state and change of village-level man-earth system: The case of three different types' villages, Henan Province[J]. Economic Geography, 26(2): 192-197.]

万晔, 司徒群, 朱䑣, 等. 2002. 云南傣族农村聚落分类体系 与建设整治途径研究 $[\mathrm{J}$ ]. 经济地理, S1: 58-62. [Wan Y, Situ Q, Zhu T et al. 2002. A study of classification systems and renovition ways of Dai Minority's settlements of Yun$\operatorname{nan}[\mathrm{J}]$. Economic Geography, S1: 58-62.]

王劲峰, 徐成东. 2017. 地理探测器: 原理与展望[J]. 地理学 报, 72(1): 116-134. [Wang J F, Xu C D. 2017. Geodetector: Principle and prospective[J]. Acta Geographica Sinica, 72(1): 116-134.]

沃尔特. 克里斯塔勒. 2010. 德国南部中心地原理[M]. 常正 文, 王兴中, 译. 北京: 商务印书馆: 1-19. [Christaller W. 2010. Germany in the Southern Center of Principle[M]. Chang Z W, Wang X Z, Trans. Beijing, China: The commercial Press: 1-19.]

谢长青, 钱文荣, 翟印礼. 2008. 公共基础设施投资与小城镇 人口非农化关系研究: 基于 1995-2006年数据的分析 [J]. 中国人口科学, 28(5): 58-65, 96. [Xie C Q, Qian W R, Zhai Y L. 2008. Empirical study on the relationships between public infrastructure investment and small town population's non- agriculturalization[J]. Chinese Journal of Population Science, 28(5): 58-65, 96.]

许学强, 周一星, 宁越敏, 等. 1996. 城市地理学[M]. 北京: 高 等教育出版社. [Xu X Q, Zhou Y X, Ning Y M, et al. 1996. Urban Geography[M]. Beijing, China: Higher Education Press.]

杨忍, 刘彦随, 郭丽英, 等. 2013. 环渤海地区农村空心化程 度与耕地利用集约度的时空变化及其耦合关系 $[\mathrm{J}]$. 地理
科学进展, 32(2): 181-190. [Yang R, Liu Y S, Guo L Y, et al. 2013. Spatial-temporal characteristics for rural hollowing and cultivated land use intensive degree: Taking the Circum-Bohai Sea region in China as an example[J]. Progress in Geography, 32(2): 181-190.]

杨忍, 刘彦随, 刘玉. 2011. 新时期中国农村发展动态与区域 差异格局[J]. 地理科学进展, 30(10): 1247-1254. [Yang R, Liu Y S, Liu Y. 2011. Regional difference and patterns of China's rural development in the new era[J]. Progress in Geography, 30(10): 1247-1254.]

杨忍, 刘彦随, 龙花楼. 2015. 中国环渤海地区人口一土地一 产业非农化转型协同演化特征[J]. 地理研究, 34(3): 475486. [Yang R, Liu Y S, Long H L. 2015. The study on nonagricultural transformation co-evolution characteristics of "population-land-industry": Case study of the Bohai Rim in China[J]. Geographical Research, 34(3): 475-486.]

杨忍, 刘彦随, 龙花楼, 等. 2016. 中国村庄空间分布特征及空 间优化重组解析 [J]. 地理科学, 36(2): 170-179. [Yang R, Liu Y S, Long H L, et al. Spatial distribution characteristics and optimized reconstructing analysis of rural settlement in China[J]. Scientia Geographica Sinica, 36(2): 170-179.]

杨志荣, 吴次芳. 2008. 制度收益与发展收益对农地非农化 进程的影响差异及其对政策调整的启示 [J]. 中国土地科 学, 22(2): 3-8, 16. [Yang Z R,Wu C F. 2008. Disparities of institutional benefit and developing benefit affecting land conversion and its inspiration to the policy adjustment[J]. China Land Science, 22(2): 3-8, 16.]

姚龙, 刘玉亭. 2015. 基于聚类分析的城郊地区乡村发展类 型: 以广州市从化区为例 [J]. 热带地理, 35(3): 427-436. [Yao L, Liu Y T. 2015. Rural development types in peri-urban areas based on cluster analysis: A case study of Conghua, Guangzhou[J]. Tropical Geography, 35(3): 427-436.]

苑韶峰, 朱从谋, 杨丽霞, 等. 2017. 人口半城镇化与产业非 农化的时空耦合分析: 以浙江省 67 县市为例 $[\mathrm{J}]$. 经济地 理, 37(3): 144-151. [Yuan S F, Zhu C M, Yang L X, et al. 2017. Spatial- temporal coupling analysis of the county population peri- urbanization and industry conversion: A case study of 67 countries and cities in Zhejiang Province [J]. Economic Geography, 37(3): 144-151.]

张小林. 1996. 苏南乡村城市化发展研究 [J]. 经济地理, 16 (3): 21-26. [Zhang X L. 1996. Study on development of rural urbanization in Southern Jiangsu Province[M]. Economic Geography, 16(3): 21-26.]

周春山, 金万富, 史晨怡. 2015. 新时期珠江三角洲城市群发 展战略的思考 $[\mathrm{J}]$. 地理科学进展, 34(3): 302-312. [Zhou C S, Jin W F, Shi C Y. 2015. Development strategy of the Pearl River Delta urban agglomeration under the current socioeconomic situation[J]. Progress in Geography, 34(3): 302-312.]

周春山, 罗彦, 陈素素. 2004. 近 20 年来广州市人口增长与分 
布的时空间演化分析 [J]. 地理科学, 24(06): 641-647. [Zhou C S, Luo Y, Chen S S. 2004. Spatial- temporal evolvement of growth and distribution of population in Guangzhou in recent twenty years[J]. Scientia Geographica Sinica, 24(6): 641-647.]

Antrop M. 2004. Landscape change and the urbanization process in Europe[J]. Landscape and Urban Planning, 67(1): 9-26.

Brown D L. 2005. Post-socialist restructuring and population redistribution in hungry[J]. Rural Sociology, 70(3): 336-359.

Erickson D L, Ryan R L, Young R D. 2002. Woodlots in the rural landscape: Landowner motivations and management attitudes in a Michigan (USA) case study[J]. Landscape and Urban Planning, 58(2): 101-112.

Li X, Xie Y, Wang J, et al. 2013. Influence of planting patterns on fluoroquinolone residues in the soil of an intensive vegetable cultivation area in northern China[J]. Science of the
Total Environment, s458-460(3): 63-69.

Lou C R, Liu H Y, Li Y F, et al. 2016. Socioeconomic drivers of $\mathrm{PM}_{2.5}$ in the accumulation phase of air pollution episodes in the Yangtze River Delta of China[J]. International Journal of Environmental Research and Public Health, 13 (10): 928 .

Pacione M. 1984. Rural Geography[M]. London: Harper \& Row Press.

Nelson P B. 2001. Rural restructuring in the American West: Land use, family and class discourses. Journal of Rural Studies, 17(4): 395-407.

Wang J F, Li X H, Christakos G, et al. 2010. Geographical detectors-based health risk assessment and its application in the neural tube defects study of the Heshun Region, China[J]. International Journal of Geographical Information Science, 24(1): 107-127.

\title{
Spatial features and forming mechanism of rural land non-agricultural degree in metropolitan areas: A case study of Guangzhou City
}

\author{
LIU Ying ${ }^{1}$, ZHOU Chunshan ${ }^{1 *}$, HUANG Wanling ${ }^{1}$, ZHU Qianqiong ${ }^{2}$ \\ (1. School of Geography and Planning, Sun Yat-sen University, Guangzhou 510275, China; 2. School of Urban \\ Planning and Design, Shenzhen Graduate School, Peking University, Shenzhen 518055, Guangdong, China)
}

\begin{abstract}
As the result of a series of significant strategic decisions promulgated by the Chinese government, including Urban and Rural Harmonious Development, New Urbanization, New Rural Construction, and the government's focus on problems facing rural areas, rural population, and agriculture, rural settlements have become a research focus of contemporary geography in China. As a key area of rapid urbanization and agglomeration of production and living factors, the land use of rural settlements in metropolitan areas changes rapidly and complicatedly, which has become an important content of research. This study divided the rural settlements into five categories and then analyzed the spatial distribution of rural land non-agricultural degree in Guangzhou City in 2013 using correlated index and GIS. The results show that: (1) Rural land non-agricultural degree decreases with the distance between a rural settlement and the metropolitan area, and increases from the outer suburb to the inner suburb. (2) There is a significant correlation between the rural land non-agricultural degree and the development level of the district centers. The distribution of non-agriculture land in inner suburb areas is zonal spread while the distribution in outer suburb areas is along the main roads. (3) The level of rural development is generally higher where major infrastructure is developed. Finally, this study analyzed the mechanism of the spatial distribution of rural land non-agriculture degree in Guangzhou City by using multiple linear regression and geographical detector. This paper provides some reference for how to use rural nonagricultural process to promote urban development, optimize and regulate rural land use, and plan village development.
\end{abstract}

Key words: non-agricultural degree of rural land; spatial feature; forming mechanism; rural settlement; metropolitan area; Guangzhou City 